\title{
Research Paper: \\ Reliability of Image Capture Technique for the Measurement of Upper Limb Active Joint Position Sense in Healthy Adults
}

\author{
Iraj Abdollahi ${ }^{1} \mathbb{( 1 )},{ }^{*}$ Elnaz Allahverdloo ${ }^{1}$
}

1. Department of Physiotherapy, University of Social Welfare and Rehabilitation Sciences, Tehran, Iran.

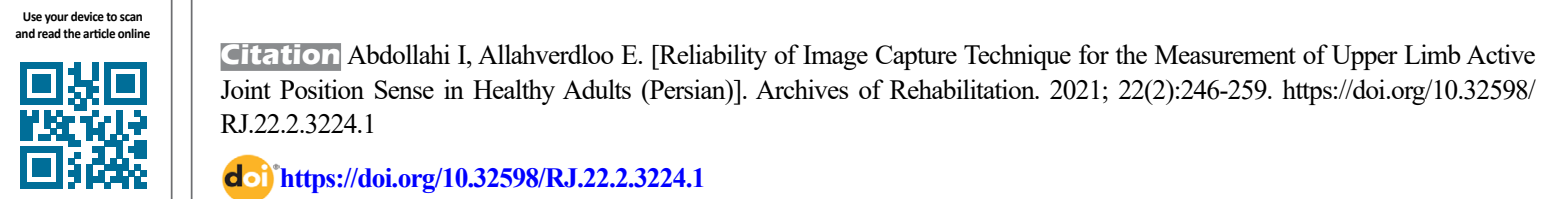

ditation Abdollahi I, Allahverdloo E. [Reliability of Image Capture Technique for the Measurement of Upper Limb Active Joint Position Sense in Healthy Adults (Persian)]. Archives of Rehabilitation. 2021; 22(2):246-259. https://doi.org/10.32598/ RJ.22.2.3224.1

dol https://doi.org/10.32598/RJ.22.2.3224.1

Received: 07 Jul 2020

Accepted: 07 Dec 2020

Available Online: $01 \mathrm{Jul} 2021$
Keywords:

Proprioception, Joint position sense, Upper limb, Image capture technique

\begin{abstract}
A B STRACT
Objective Proprioception is the conscious perception of limb position, motion, balance, and pressure. It has a vital role in movement control, especially motor planning and neuromuscular feedback mechanism. To investigate the proprioceptive function, it is essential to use the best measurement method. Different techniques and approaches have been introduced, which are usually expensive and not applicable for clinical use. One of these methods is the image capture technique which is easy and practical. Stillman introduced this technique to measure the joint position sense of the knee considering all variables affecting it and reported its good reliability. Many studies have used this technique for knee and lower limb joints and reported its good reliability, while few studies have used this technique for the upper limb joints. Therefore, this study investigates the reliability of the image capture technique for measuring the Active Joint Position Sense (AJPS) of the left shoulder and elbow in healthy adults. If it yields a good result, it can be used as an available and cost-effective method by clinicians.

Materials \& Methods In this methodological study, the participants were 10 healthy adults (5 men, 5 women) aged 18-40 years. To assess the AJPS, we used image capture technology which is one of the most reliable methods for the lower limb joint position sense measurement. Markers were attached on elbow and shoulder landmarks, and photos were taken during the reproduction of angles by participants. Then, the photos were entered into AutoCAD software, and the angles were calculated by drawing line segments from landmarks and connecting them. The absolute error and relative error (the difference between the initial and reproduced angles) were used to measure accuracy. The AJPS was assessed for internal and external rotation of the shoulder and elbow flexion. The measurements were repeated two hours later to assess intra-day reliability and two days later to assess inter-day reliability. Interclass Correlation Coefficient (ICC) and Standard Error of Measurement (SEM) were used for statistical analysis. Results The ICC of inter-day reliability of the test for all shoulder and elbow movements in relative and absolute errors was reported as excellent $(\geq 0.92)$. Intra-day reliability was reported excellent $(\geq 0.90)$ for elbow flexion, and internal rotation of the shoulder in both relative and absolute errors were excellent (0.94). For external rotation of the shoulder, it was excellent in relative error (0.94) and good in absolute error (0.80). All measurements had absolute reliability based on the SEM results.
\end{abstract}

Conclusion The image capture technique is a simple, cost-effective, and available method tool for measuring AJPS and proprioception in upper limbs by clinicians and researchers.

\section{${ }^{*}$ Corresponding Author: \\ Elnaz Allahverdloo, MSc.}

Address: Department of Physiotherapy, University of Social Welfare and Rehabilitation Sciences, Tehran, Iran.

Tel: +98 (901) 2681077

E-Mail: elnazallahverdlo@gmail.com 


\section{Extended Abstract}

\section{Introduction}

$\mathbf{P}$

roprioception is the conscious and unconscious perception of limbs, joint position, sense of movement, and sense of force [1]. Joint proprioception arises from a set of afferent messages from muscle mechanoreceptors, tendons, joint capsules, ligaments, and skin. The receptors involved in proprioception include muscle spindles and the Golgi tendon organ [2,3]. These muscle-tendon receptors transmit information about the static length of the muscles, the change in muscle length, and the force produced by the muscles to the central nervous system [4]. Given that most of the mechanoreceptors associated with proprioception are active at the end range of motion of a joint, the muscle spindle plays a unique role in transmitting proprioceptive messages [5].

For this reason, static proprioception tests are not practical enough because inactive movements do not stimulate the muscle spindle, which is a very sensitive mechanoreceptor [6]. Studies have shown that after damage to the joint capsule, ligament, labrum, or muscles involved, the proprioception gets impaired [7-10]. Damage to the tissues that contain mechanoreceptors causes a relative reduction in afferent messages, which can lead to impaired proprioception and make a person prone to re-injury due to a decrease in proprioceptive feedback [11]. Proprioception and vision together play a special role in controlling movements [12]. Therefore, it is imperative to study proprioception to rehabilitate and prevent re-injury $[13,14]$ properly.

Joint position sense, which is one of the components of proprioception, is a measure of the ability to reproduce a joint angle accurately. This sensation is done actively and passively, and the amount of angle error is a good criterion for measuring the sense of joint position [15]. To measure the joint position sense, various tools and methods, such as electrogoniometer, Biodex machine [16], inclinometer, motion analyzer [17], isokinetic dynamometer [18], and image capture technique [19] have been used. However, these methods are expensive and specialized. Also, they require a lot of space and are unusable in medical settings. Stillman first proposed the image capture technique in 2000 [6]. Unlike other methods, it does not require complex tools and is not limited to use in laboratories. Smith et al., in a review to determine the reliability of knee joint position sense assessment measures, reported good reliability of image capture technique [20]. This technique has been proposed as an acceptable method for measuring the joint position sense of lower limbs [21, 22]. However, few studies have mea- sured the joint position sense of upper limbs by this technique $[23,24]$. Olyayi used the image capture technique in a case study and reported its good reliability [23], but for better knowledge, we need a study with a larger sample size. In a review study by Ager et al. on different methods of measuring the sense of active and passive shoulder joint position, the dynamometer showed the highest reliability $(0.92)$, and the image capture technique had the highest reliability (0.81) for measuring the sense of passive shoulder joint position [24]. Because of the differences in the joints of upper and lower limbs, where the lower limbs are for weight-bearing and walking, and the upper limbs are for movement and delicate tasks, studies are needed to evaluate the reliability of image capture technique for the upper limb joints. Therefore, this study aims to evaluate the reliability of the image capture technique for measuring Active Joint Position Sense (AJPS) in upper limbs to be used as an accessible and usable method in clinics.

\section{Materials and Methods}

This research is a methodological study. By using a convenience non-probability sampling method, 10 healthy individuals (5 females and 5 males) aged 18-40 years [25] were selected from the students of the University of Social Welfare and Rehabilitation Sciences in Tehran, Iran, in 2019. The sample size was determined according to Relph et al. [21] and using Equation 1. The study process was explained to the participants, and they completed a form containing personal information and signed a consent form to participate in the study. The inclusion criteria were being right-handed (In healthy right-handed people, proprioception in the non-dominant hand is more accurate [25] and no left upper limb injury in the past 6 months [6].

$$
\operatorname{var} \tilde{\rho}_{I}=\frac{2\left(1-\tilde{\rho}_{I}\right)^{2}\left(1+(k-1) \tilde{\rho}_{I}\right)^{2}}{k(k-1)(n-1)}, n=8 z_{\frac{\alpha}{2}}^{2} \frac{\left(1-\tilde{\rho}_{I}\right)^{2}\left(1+(k-1) \tilde{\rho}_{I}\right)^{2}}{\left.k(k-1) \omega^{2}\right)+1}
$$

The subjects attended two similar test sessions two days apart. In each session, the AJPS of the left shoulder and elbow was measured through active reproduction of angles and using the image capture technique. The joints were examined in random order, and the participants were asked to guess the order of shoulder or elbow joint measurements without knowing the contents of the sheets in the envelope. To measure each joint, the respective landmarks were first identified with black circular markers (2-cm diameter). Then, a 16-megapixel digital camera was placed at a distance of $1 \mathrm{~m}$ and aligned with the joint level.

The measurement of the AJPS of the elbow was done while the patient was sitting on a chair without an armrest 


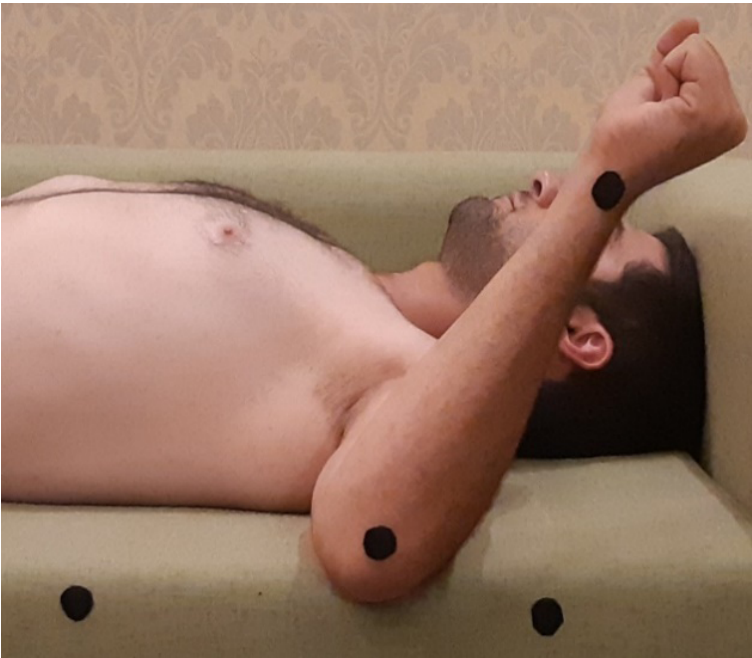

Archives of

Rehabilitation

Figure 1. Active reproduction of the joint angle for shoulder external rotation by the participant

and with closed eyes. Elbow landmarks were affixed to the outer edge of the acromion, lateral epicondyle, and between the distal radioulnar joint. The examiner then created the 100-degree angle with a goniometer. After a pause of two seconds, the elbow was returned to its original position, and the participant was asked to reproduce the angle, pause for two seconds, and return to the original position, repeating this maneuver two more times. In each of these steps, a photograph of the angle reproduced by the participant was taken by the camera. The AJPS of the shoulder was measured in the supine position, and the markers were placed on the tip of the ulna and olecranon bones and on both sides of the hands on the bed. The initial position was at 90 degrees angle for the shoulder and elbow; 50 degrees was applied for internal rotation of the shoulder and 30 degrees for its external rotation. The initial angle was measured with a goniometer, and then the participant performed the rotation with their eyes closed, and a photograph of the angle was taken in each repetition. All these steps were done again 2 hours later and 2 days later. Figures 1 and 2 show the active reproduction of the angles for the shoulder and elbow. At

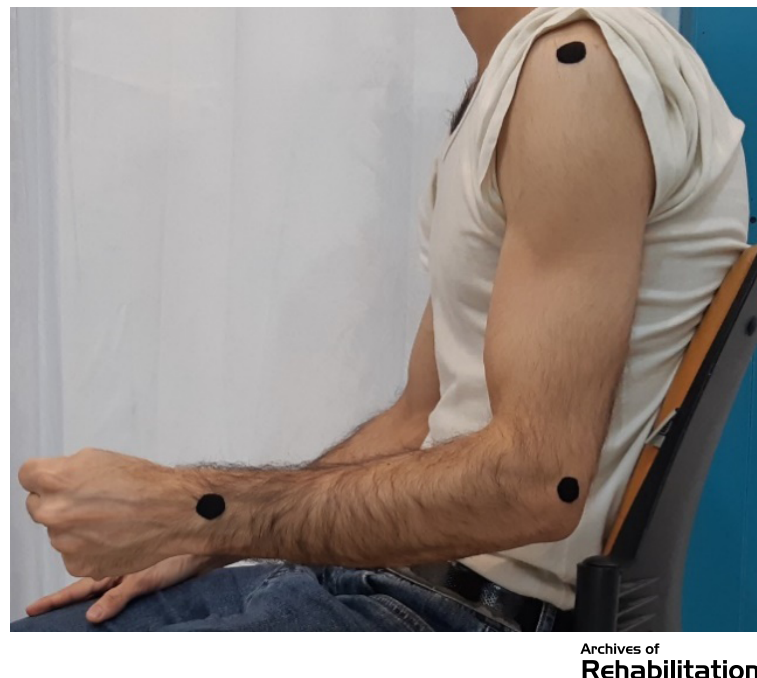

Figure 2. Active reproduction of the joint angle for elbow flexion by the participant

the end of the three phases of evaluation, we imported the relevant photos into the AutoCAD program and obtained the angles by creating line segments from the marker places and connecting them. To obtain the angle reproduction error, the values of absolute error (i.e., the difference between the produced angle and the initial angle without considering the direction of motion) and relative error (i.e., the difference between the produced angle and the initial angle with considering the direction of motion) were calculated [22]. These values for each joint were entered into SPSS v. 19 software. The within-group comparison was performed between the results of the first and second phases to assess intra-day reliability of the test, and a between-group comparison was carried out between the results of the first and third phases to evaluate its inter-day reliability. We used ICC, $95 \%$ test power, a significance level of 0.05 , and SEM to evaluate absolute repeatability between measurements.

\section{Results}

The characteristics of height, weight, and Body Mass Index (BMI) of the participants are presented in Table 1. The

Table 1. Demographic characteristics of the participants

\begin{tabular}{ccc}
\hline Characteristics & Mean \pm SD & Median \\
\hline Age $(\mathrm{y})$ & $29.1 \pm 4.79$ & $21-37$ \\
\hline Weight $(\mathrm{kg})$ & $76.3 \pm 12.57$ & $60-86$ \\
\hline Height $(\mathrm{cm})$ & $173.7 \pm 11.52$ & $158-190$ \\
\hline Body mass index $\left(\mathrm{kg} / \mathrm{m}^{2}\right)$ & $25.52 \pm 2.88$ & $30.86-21.8$ \\
\hline
\end{tabular}

Rehabives of 
Table 2. Mean and Standard Deviation (SD) of relative and absolute errors in 3 measurements

\begin{tabular}{ccccc}
\hline \multicolumn{2}{c}{ Type of Movement } & \multicolumn{3}{c}{ Mean \pm SD } \\
\cline { 3 - 4 } & & The First Measurement & The Second Measurement & The Third Measurement \\
\hline & Shoulder external rotation & $1.33 \pm 3.24$ & $0.56 \pm 4.39$ & $1.36 \pm 3.06$ \\
$\begin{array}{c}\text { Relative error } \\
\text { (degree) }\end{array}$ & Shoulder internal rotation & $-7.2 \pm 2.98$ & $-7.36 \pm 3.0$ & $-6.63 \pm 3.25$ \\
& Elbow flexion & $-5.73 \pm 2.01$ & $-6.4 \pm 1.85$ & $-5.8 \pm 1.84$ \\
\hline $\begin{array}{c}\text { Absolute error } \\
\text { (degree) }\end{array}$ & Shoulder external rotation & $2.03 \pm 1.59$ & $3.63 \pm 2.54$ & $3.30 \pm 1.52$ \\
& Shoulder internal rotation & $7.26 \pm 2.81$ & $7.56 \pm 2.50$ & $6.90 \pm 2.68$ \\
\hline
\end{tabular}

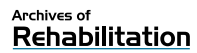

mean and standard deviation of absolute and relative errors obtained from the three measurements are shown in Table 2. All $P$ values were $\leq 0.005$. According to Shrout's ICC classification [26], ICC $<0.40$ indicates poor reliability, 0.400.75 indicates moderate reliability, and ICC $>0.75$ shows excellent reliability. The high ICC for absolute and relative errors in internal and external shoulder rotations and elbow flexion measured in one day indicated that the image capture technique had excellent inter-day reliability to assess AJPS. The high values of ICC for all measurements in several days also indicated the excellent intra-day reliability of this technique. SEM value was also greater than the mean difference in all measurements, indicating absolute repeatability between measurements. Table 3 shows the ICC and SEM values for the measurements.

\section{Discussion and Conclusion}

Excellent ICC for relative error (0.9) and absolute error $(0.8)$ of all movements and three measurements indicated high reliability of the joint image capture technique. Olyayi, in a similar study, used the image capture technique by digital camera for the shoulder joint at angles of 30, 45, 65, and 70 degrees while the goniometer was attached to the joint. The obtained results of absolute and relative error of each angle (0.97) showed excellent inter-day reliability of the technique [23]. One of the limitations of their study was its small sample size, which limits the possibility of generalizing the results. Irving et al. compared the reliability of measuring the sense of knee joint position with a goniometer and image capture technique, measured by two examiners in standing position at angles of 20, 40, 75, and 100 degrees. IPad2 was used for taking images, and only one image was taken from each angle, and the participants returned for a second measurement a week later. Their results

Table 3. ICC and SEM values of inter-day and intra-day reliability

\begin{tabular}{|c|c|c|c|c|c|}
\hline \multirow{2}{*}{\multicolumn{2}{|c|}{ Type of Movement }} & \multicolumn{2}{|c|}{ Inter-day Reliability } & \multicolumn{2}{|c|}{ Intra-Day Reliability } \\
\hline & & $\begin{array}{l}\text { Intraclass Correla- } \\
\text { tion Coefficient }\end{array}$ & $\begin{array}{c}\text { Standard Error of } \\
\text { Measurement }\end{array}$ & ICC & SEM \\
\hline \multirow{3}{*}{ Relative error } & Shoulder external rotation & 0.98 & 0.71 & 0.94 & 1.73 \\
\hline & Shoulder internal rotation & 0.96 & 1.21 & 0.98 & 0.79 \\
\hline & Elbow flexion & 0.96 & 0.71 & 0.90 & 1.16 \\
\hline \multirow{3}{*}{ Absolute error } & Shoulder external rotation & 0.92 & 0.84 & 0.8 & 1.70 \\
\hline & Shoulder internal rotation & 0.93 & 1.35 & 0.97 & 0.86 \\
\hline & Elbow flexion & 0.96 & 0.68 & 0.90 & 1.11 \\
\hline
\end{tabular}


for the goniometer and image capture technique showed poor to moderate reliability [27]. This result can be related to the long period between two measurements and taking only one picture from an angle [28]. In another study by Relph, the reliability (ICC) of the image capture technique for the knee joint in the sitting and prone positions was reported to be 0.96 by one tester and 0.98 by several testers [21]. For the goniometer, a study reported poor to moderate reliability for measuring the wrist joint position sense at 20 and 45 degrees of extension and flexion, where at $20^{\circ}$ flexion angle, it was more reliable [15]. In Dover et al.'s study, an inclinometer was used to measure the AJPS, and a dynamometer was used to measure shoulder force reproduction. They reported very high reliability (0.99). However, they only calculated absolute error [29], while it is better to use relative error because relative error also determines the direction of movement. The inclinometer, like other methods used in studies, has a less clinical aspect.

Few review studies have been performed to find the best measure of the sense of shoulder joint position, which has validated the passive test for the shoulder in the 90-degree abduction and internal rotation [24]. The isokinetic dynamometer has also been suggested as an efficient method for assessing the sense of joint position. Despite low reliability, it allows the evaluation of the cerebral hemispheres in terms of sensorimotor abilities [30]. However, it is not possible to use these facilities in all medical centers. In a study by JuulKristensen, the AJPS of the elbow was measured by an electrogoniometer, and the passive joint position sense was measured by the device. The results showed moderate reliability (0.59 and 0.69) for absolute error and poor reliability for variable error of AJPS measured by electrogoniometer [31].

The image capture technique has reliability for measuring the AJPS of the shoulder and elbow. The simplicity and availability of this measurement method make it possible to use it extensively in medical centers and especially in the rehabilitation treatment process to evaluate joint proprioception.

\section{Ethical Considerations}

Compliance with ethical guidelines

All ethical principles are considered in this article. The participants were informed about the purpose of the research and its implementation stages. They were also assured about the confidentiality of their information and were free to leave the study whenever they wished, and if desired, the research results would be available to them. Also, this study was approved by the ethics committee of the University of Social Welfare and Rehabilitation Sciences.
Funding

This research did not receive any grant from funding agencies in the public, commercial, or non-profit sectors.

Authors' contributions

All authors equally contributed to preparing this article.

\section{Conflict of interest}

The authors declared no conflict of interest.

\section{Acknowledgments}

The authors would like to thank the participants and $\mathrm{Mr}$. Mohsen Khalifpour for their cooperation. 


\section{مقاله بزّوهشى: \\ تكراريذيرى اندازهكيرى حس وضعيت مفصلي با استفاده از تكنيك عكسبردارى در اندام فوقاني \\ ايرج عبداللهى' (ه) •الناز اللهوردلو' \\ ا. كروه فيزيوترايی، دانشكاه علوم توانبخشى و سلامت اجتماعى، تهرانه ايران.}

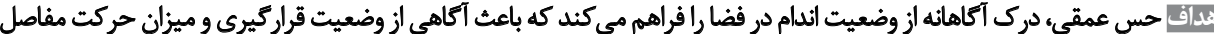

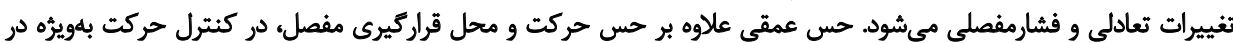

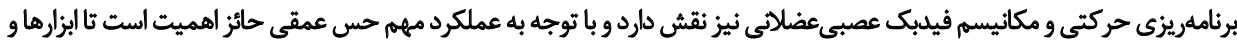

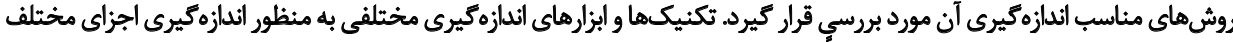

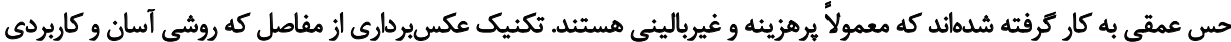

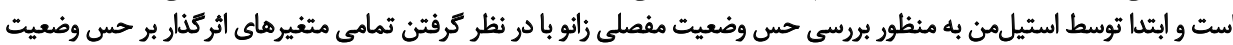

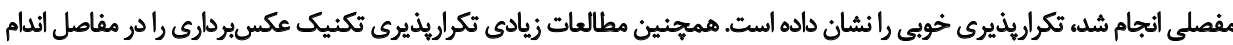

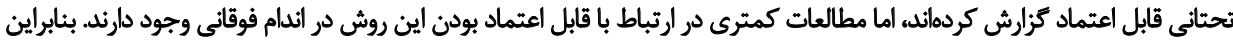

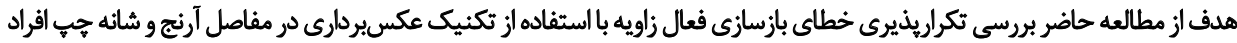

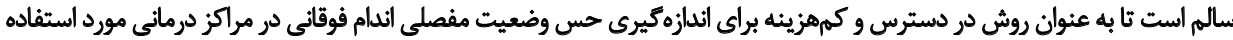

قرار كيرد.

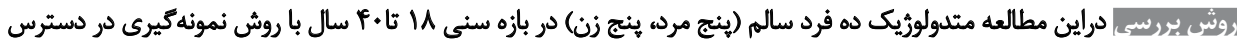

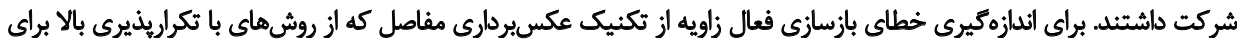

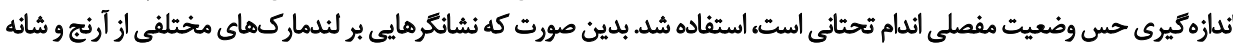

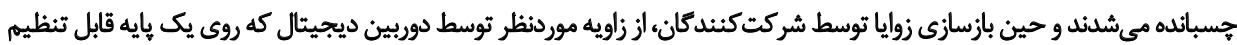

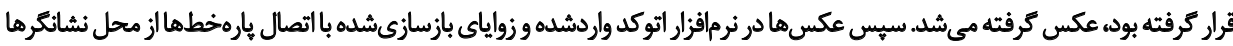

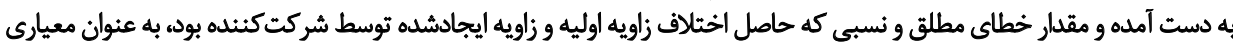

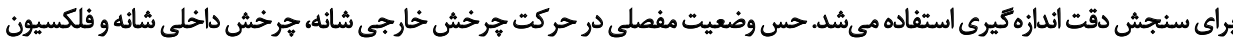

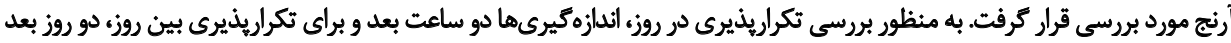

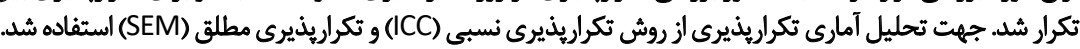

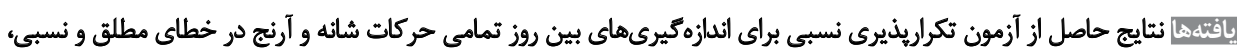

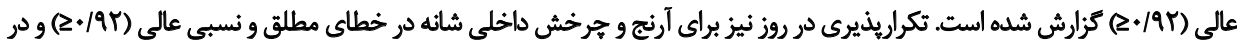

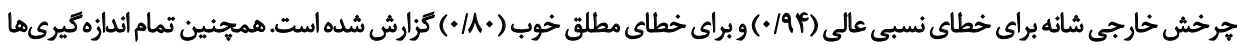

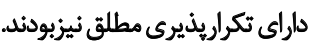

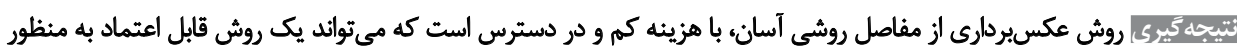

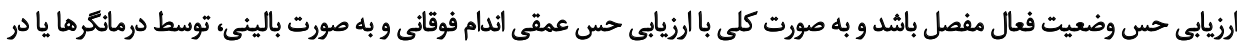
تحقيقات مورد استفاده قرار كيرد.

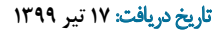

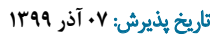

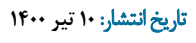

كليدواثهها:

حس عمقى، تحرئ تكراريذيرى، خطاى، بازئ بازسازى زاويه، اندام فوقاني، تكنيك زازيك عكس بردارى مفاصل تئيك

"نويسينده مسئول:

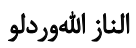
نشائي: تُهران، دائشكاه علوم توانبخشي و سلامت اجتماعي، كروه فيزيوترايبي. تلفئ رايانامه: elnazallahverdlo@gmail.com 
سال . . . ميلادى مطرح شد كه از جمله تكنيكهاى كاربردى

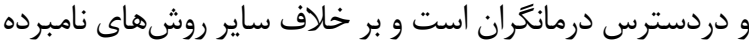

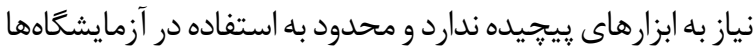

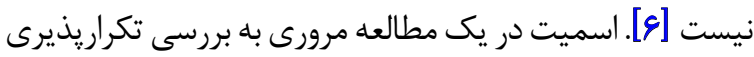

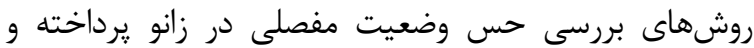

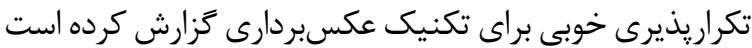

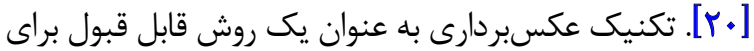

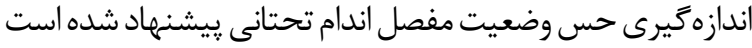

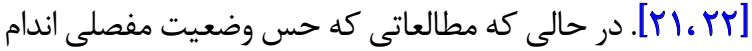

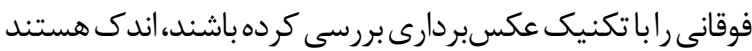

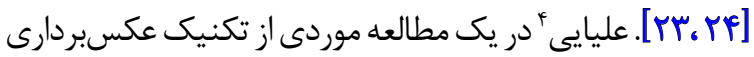

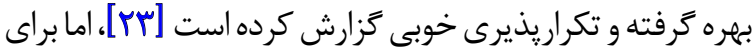

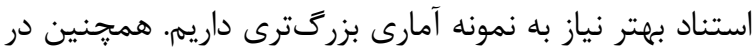

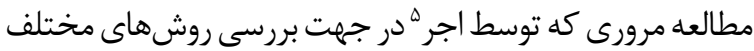

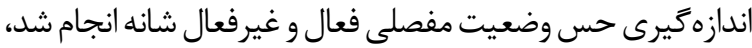

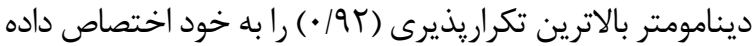

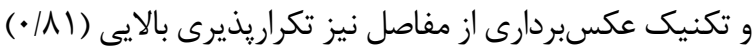

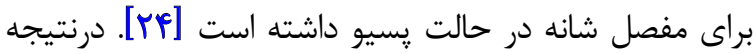

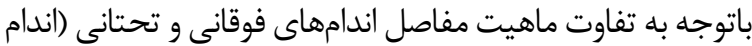

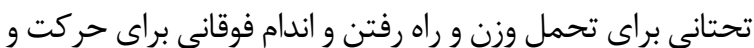

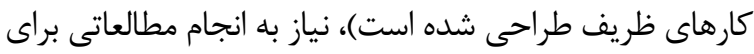

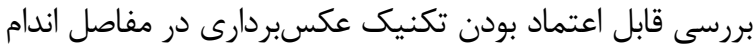

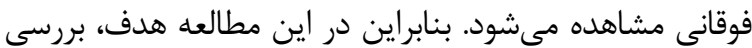

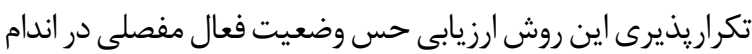

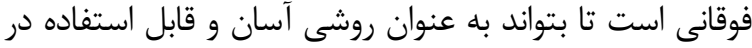
بالين به كاركرفته شود.

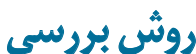

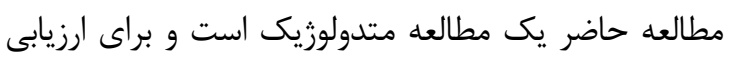
تكراريذيرى با روش نمونه ئيرى ساده غير احتمالى، ده فرد سالم

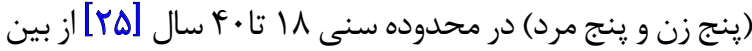

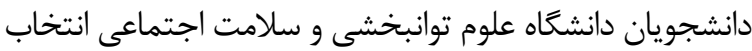

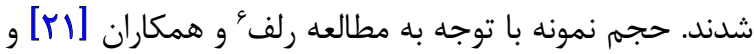

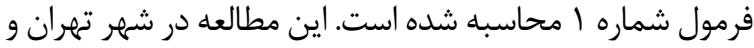

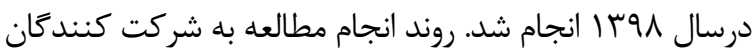

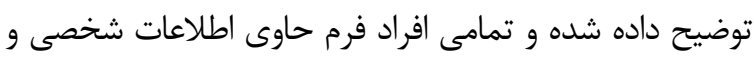

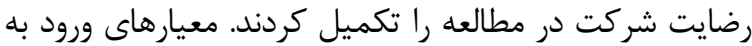

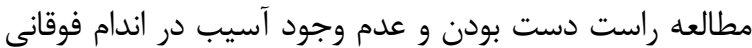

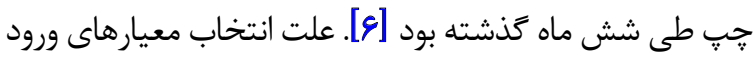

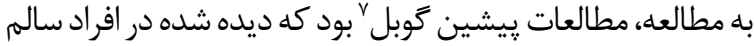

راست دست، حس عمقى در دست غيرغالب دقيقتر است.

\section{Olyayi}

5. Ager

6. Relph

7. Goble

حس عمقى يا يرويريوسيشن درك آكاهانه و نآَاهانها از وضعيت

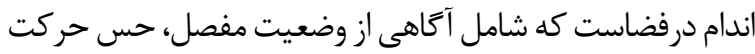

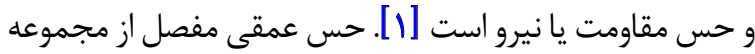

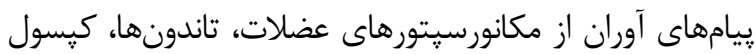

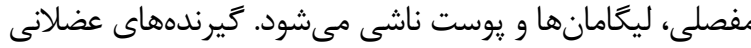

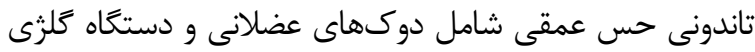

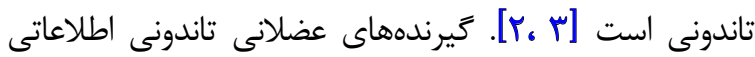

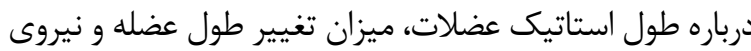

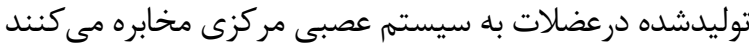

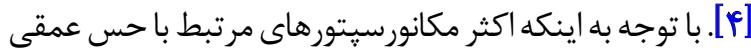

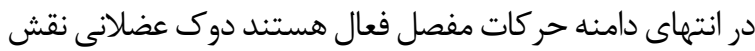

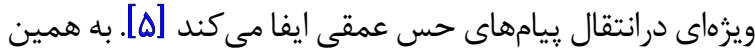

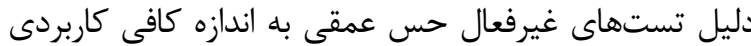

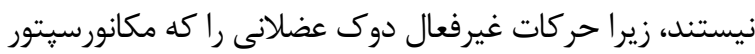

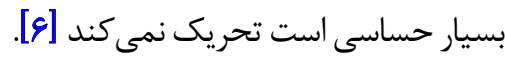

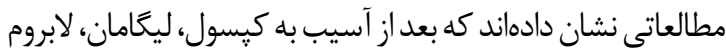

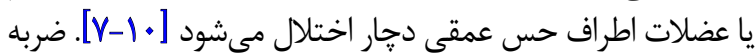

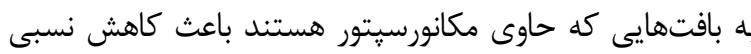

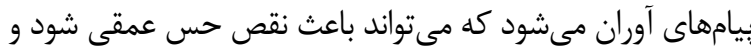

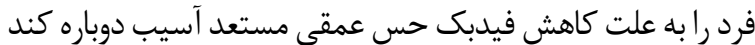

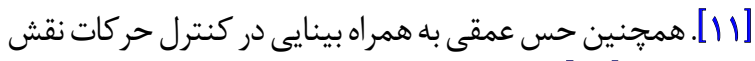

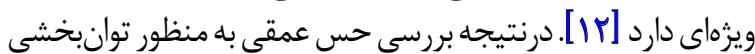

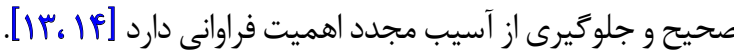
حس وضعيت مفصل' كه يكى از اركان حس عمقى است،

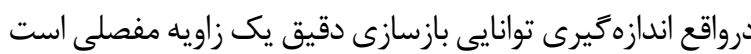

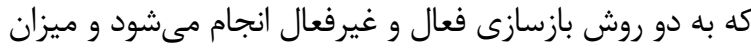

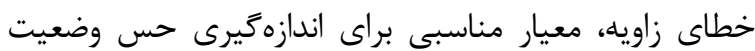

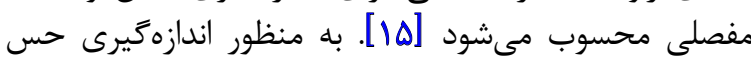

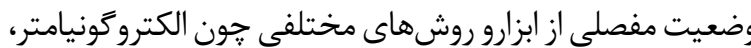
[IV]Inclinometer ، Motion analyzer [19 Biodex

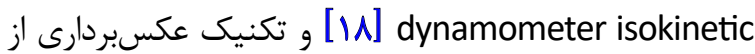

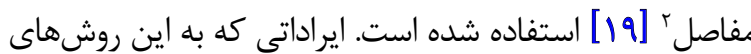

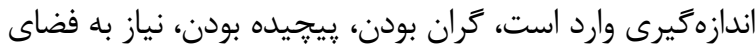

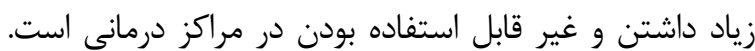

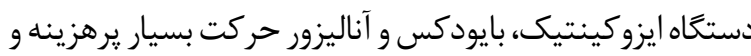

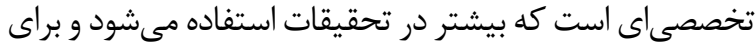

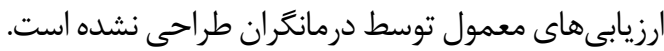
تكنيك عكسبردارى از مفاصل كه ابتدا توسط استيلمنَّدر 
اوليه زاويه •9 • · شانه و آرنج بود كه براى جرخش داخلى شانه

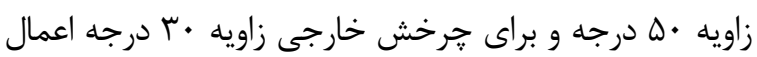

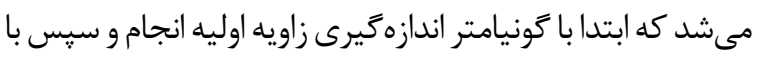

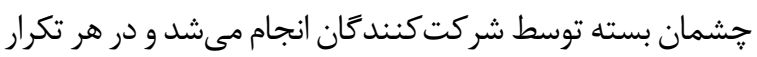

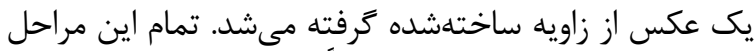

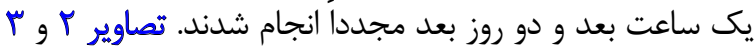

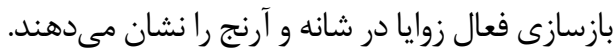
يس از يايان سه جلسه، عكسهاى مربوطه را در برنامه اتوكد

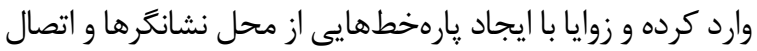

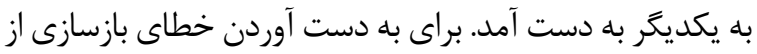

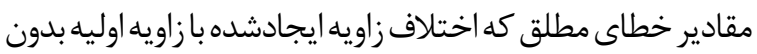

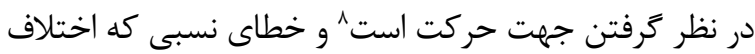

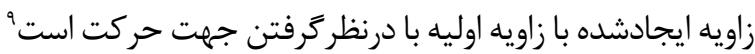

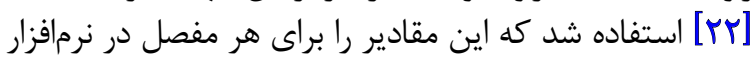

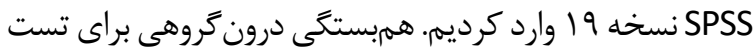

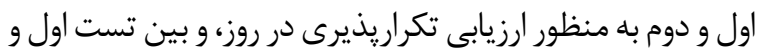

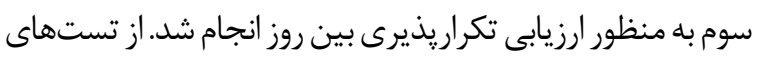

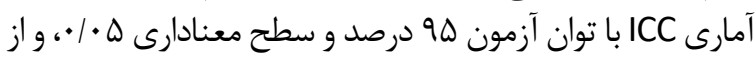
SEM

Ldict

ويزگى هاى قد، وزن و شاخص توده بدنى شركت كنند

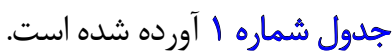

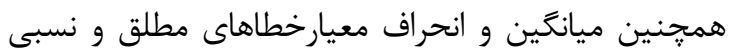
بلهدستآمده در سه بار اندازهخيرى در جدول شماره † آمده است.

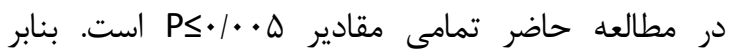

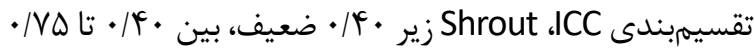

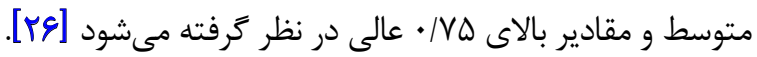

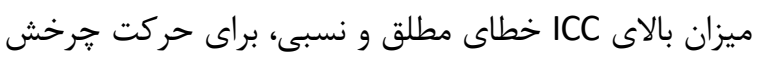

\section{Absolute error} 9. Relative error $\operatorname{var\tilde {\rho }_{I}}=\frac{2\left(1-\tilde{\rho}_{I}\right)^{2}\left(1+(k-1) \tilde{\rho}_{I}\right)^{2}}{k(k-1)(n-1)}$

$\omega=2 z_{\frac{\alpha}{2}}^{2}\left(\operatorname{var} \tilde{\rho}_{I}\right)^{\frac{1}{2}}$

$n=8 z^{2} \frac{\alpha}{2} \frac{\left(1-\tilde{\rho}_{I}\right)^{2}\left(1+(k-1) \tilde{\rho}_{I}\right)^{2}}{\left.k(k-1) \omega^{2}\right)+1}$

افراد در دو جلسه آزمون مشابه كه با فاصله دو روز انجام

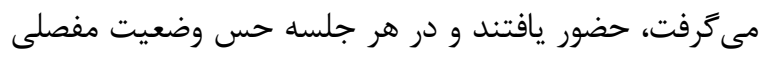

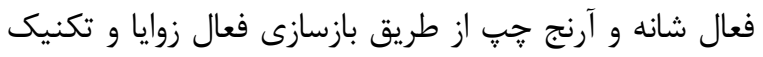

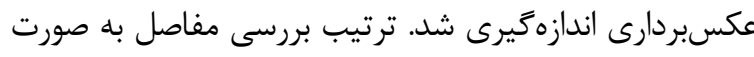

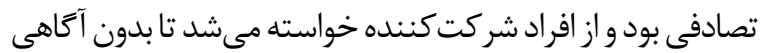

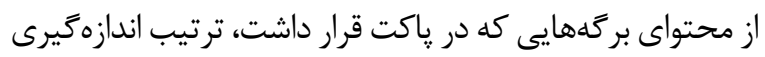

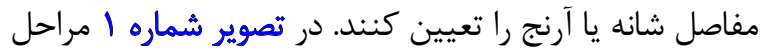
انجام مطالعه به اختصار نشان داده شده است.

براى اندازهخيرى هر مفصل ابتدا لندماركهاى مربوطه با

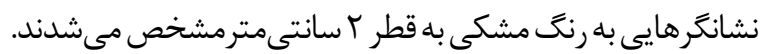

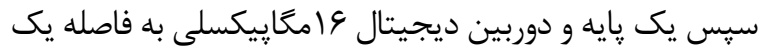

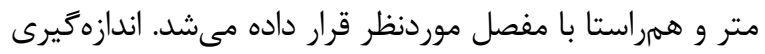

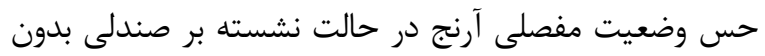

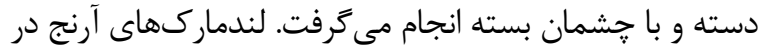

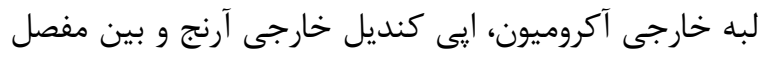

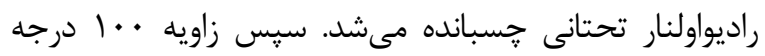

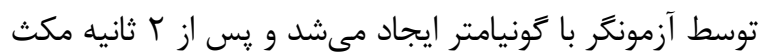

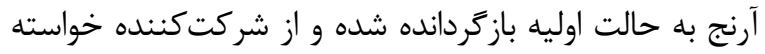

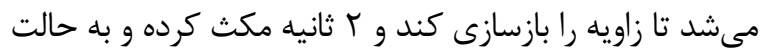

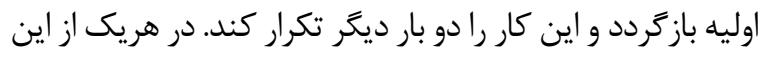

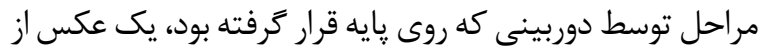

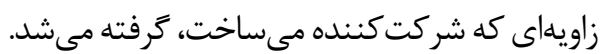

به منظور اندازهخيرى حس وضعيت مفصلى شانه، فرد طاقباز روى تخت دراز كشيده و نشانگرها در محل سر استخوان اولنا،

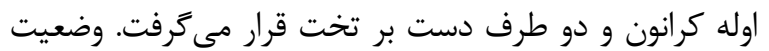

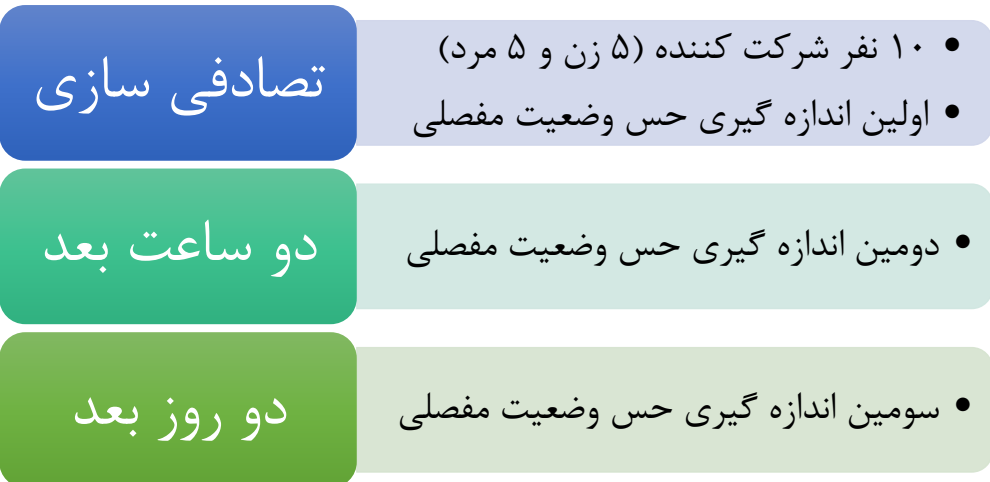




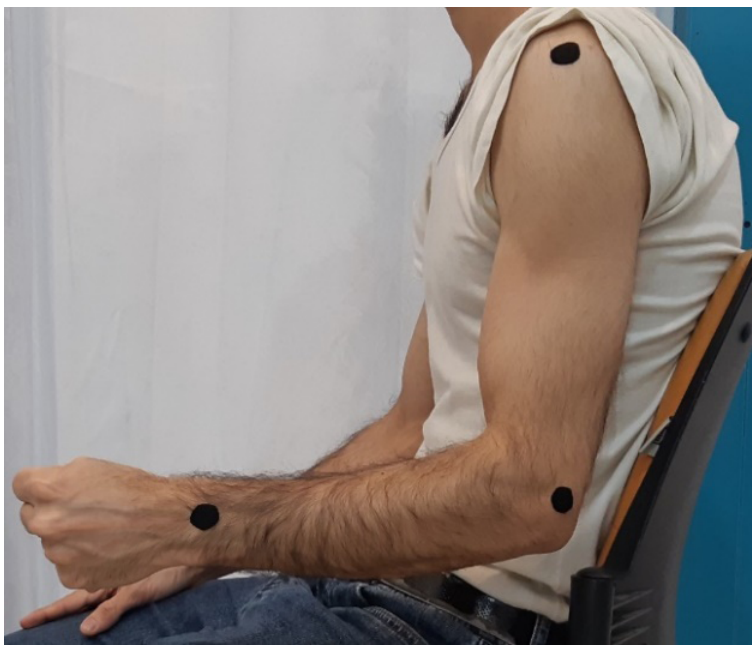

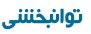

تصوير بّ. بازسازي فعال زاويه در فلكشن آرنج توسط شركت كنيدكان

در مطالعه مشابهى كه توسط ايروينغَ' انجام شد با تكنيك

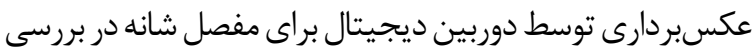

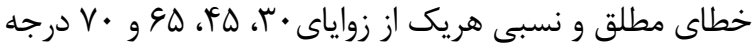

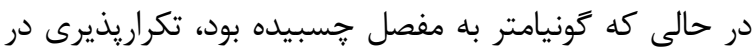

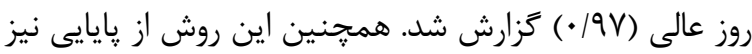

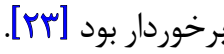
ايروينَ و همكار انش به منظور مقايسه تكراريذيرى اندازهيرى

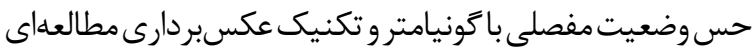

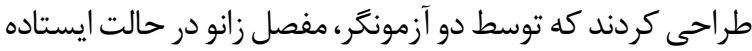

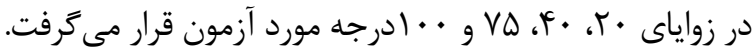

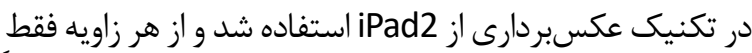

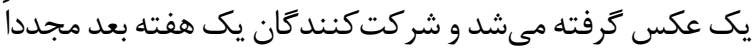

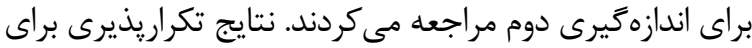

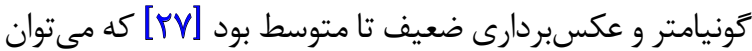

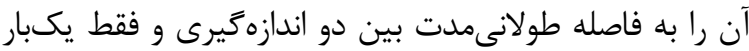

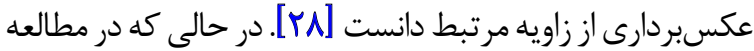

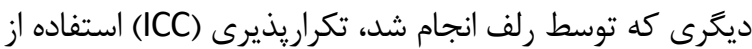

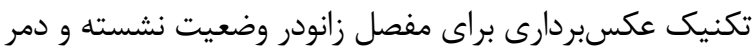

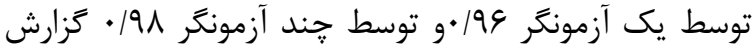
10. Olyayi

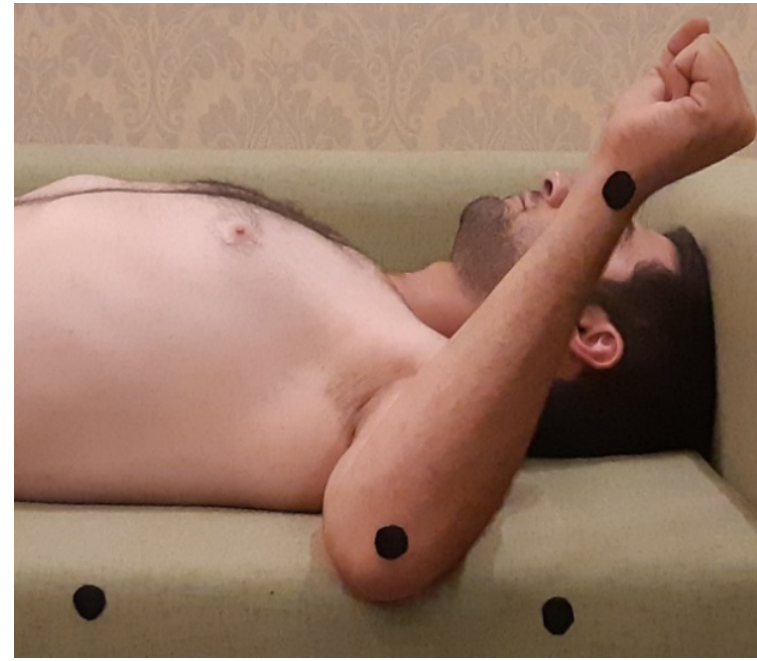

توانبخنتى

تصوير Гا. بازسازى فعال زاويه در جرخش خارجى شانه توسط شركت كنيدكان تواني

داخلى و خارجى شانه و فلكشن آرنج در يك روز نشان مىدهي إند

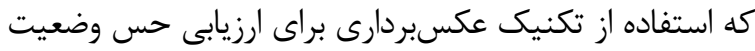

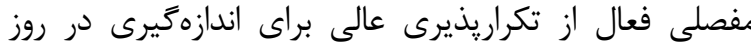

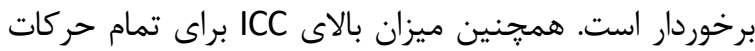

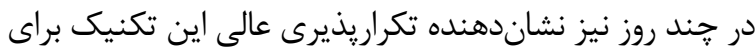
اندازهيرى بين روز است.

نيز در تمام موارد از اختلاف ميانگَينها بيشتر است كه

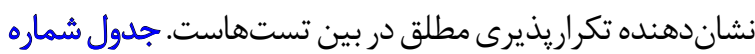

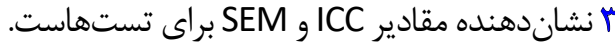

بحث

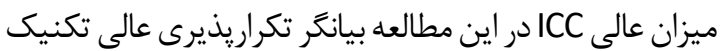

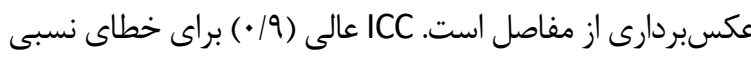

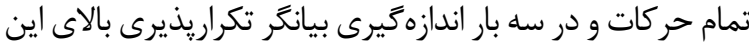

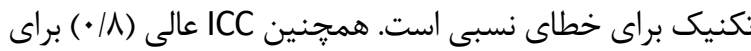

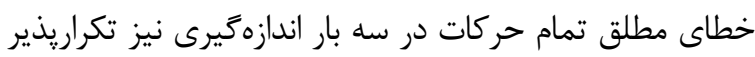

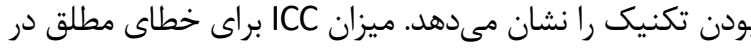

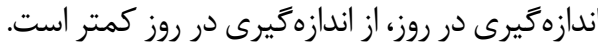

جدول (. ويرُكى هاى جمعيتشناختى شركت كنيندان در مطالعه حاضر

\begin{tabular}{|c|c|c|}
\hline دامثه & مياتكيندانحراف معيار & مثغير \\
\hline$r M-M$ & $r q / \backslash \pm F / M$ & سن (سال) \\
\hline $8 \cdot-N$ & $V E / r \pm I r / \Delta V$ & وزن (كيلو كرم) \\
\hline $104-19$. & $I V T / N \pm I V / A T$ & قدا (سانتى متر) \\
\hline$r / \Lambda-r+/ N e$ & $r \Delta / \Delta Y \pm Y / M$ & BMI \\
\hline
\end{tabular}


جدول r. ميانكين و انحراف معيار خطاهاى نسبى و مطلق در سه بار اندازهيرى

\begin{tabular}{|c|c|c|c|c|}
\hline \multicolumn{3}{|c|}{ ميانكيندانحراف معيار (درجه) } & \multirow{2}{*}{\multicolumn{2}{|c|}{ نوع حركت }} \\
\hline أندازهيرى سوم & اندازهكيرى دوم & اندازهكيرى اول & & \\
\hline$r / .9 \pm 1 / \% e$ & $E / T a \pm . / A C$ & Tr/TYI/TI & خرخش خارجى شانه & \\
\hline$r / T \Delta \pm-g / R^{\prime}$ & $r \pm-r / r q$ & $r / Q A \pm-V / T$ & 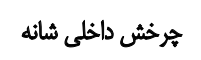 & خطاى نسبى \\
\hline $\mid / A r \pm-\Delta / A$ & $V / A \Delta \pm-8 / 9$ & $r / \cdot 1 \pm-\Delta / M^{n}$ & قلكشن آرنج & \\
\hline V/AY $\pm r / T$. & $r / \Delta F \pm r / Q T$ & $1, \Delta 9 \pm r / \cdot r$ & هرخ خارجى شانه & \\
\hline r/FN土\&/9. & $T / \Delta \cdot \pm V / \Delta S$ & $r / \Lambda) \pm V / Y e$ & هرخش هاخلى شائه & خطاى مطلق \\
\hline$V / \Lambda f \pm \Delta / \Lambda$ & $1 / \Delta \Delta \pm g / 4$. & $V / N \in \pm \Delta / A$. & فلكشن آرنج & \\
\hline
\end{tabular}

تاكنون مطالعات مرورى اندكى به منظوردسترسى به بهترين

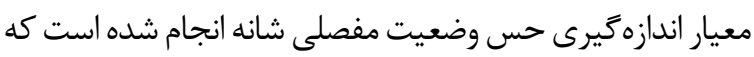

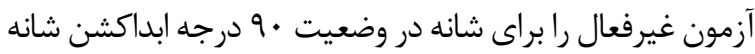

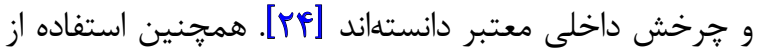

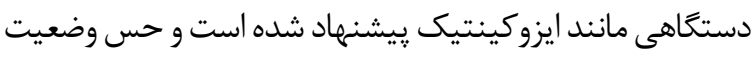

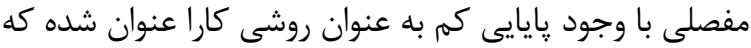

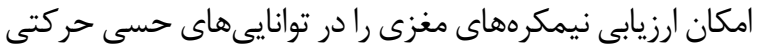

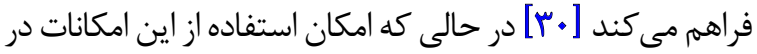
تمامى مراكز درمانى وجود ندارد.

در يك مطالعه كه توسط جول-كريستنسن" انجام شد تكراريذيرى حس وضعيت فعال مفصلى آرنج توسط الكترو گونيامتر

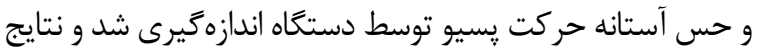

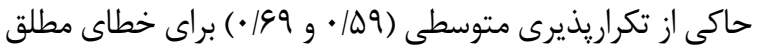

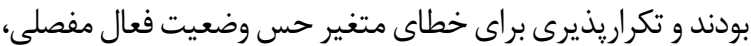

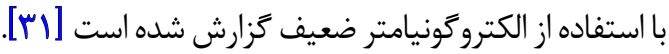

شده است [YY]]. از تكنيكهاى ديخرى كه براى حس وضعيت مفصلى استفاده

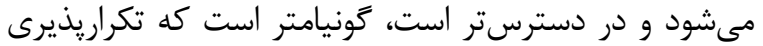

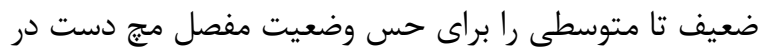

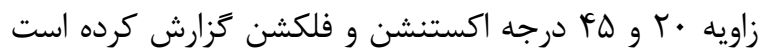

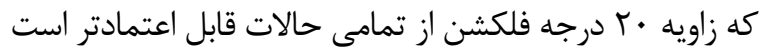

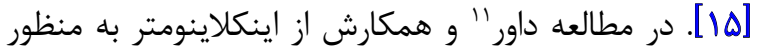

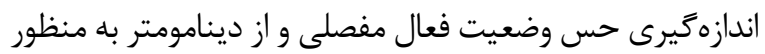

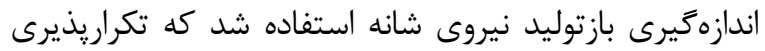

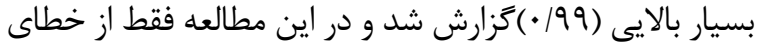

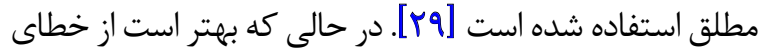

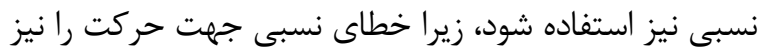

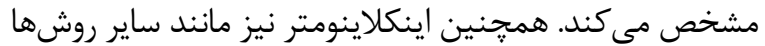

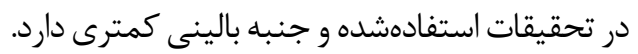

جدول r. ضرايب SEM و ICC تكراريذيرى بين روز و تكراريذيرى در روز

\begin{tabular}{|c|c|c|c|c|c|}
\hline \multicolumn{2}{|c|}{ تكراريذيرى در روز } & \multicolumn{2}{|c|}{ تكراريذيرى بين روز } & \multirow{2}{*}{\multicolumn{2}{|c|}{ نوع حركت }} \\
\hline SEM & ICC & SEM & ICC & & \\
\hline $1 / n$ &.$/ 98$ & $\cdot M$ &.$/ 94$ & هرخش خارجى شانه & \\
\hline$M$ & .194 & $M / T I$ & .19 & هرخش داخلي شائه & خطاى نسبي \\
\hline Me &.$/ 9$. & $\cdot M$ & .19 & فلكشن آرنج & \\
\hline $\mathbb{N}$ &.$/ 1$ & $\cdot /$ Af &.$/ 94$ & هرخش خارجى شانه & \\
\hline.$/ N$ &.$/ 9 y$ & $1 / N \Delta$ & זום & جرخش داخلى شائه & خطاى هملقق \\
\hline$M / 1$ &.$/ 9$ & .181 &.$/ Q$ & فلكشن آرنج & \\
\hline
\end{tabular}


نتيجليَّى

نتايج به دست آمده از مطالعه حاضر نشان ميدهد ارئ اريابى

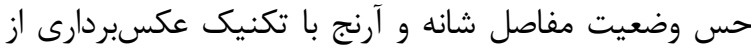

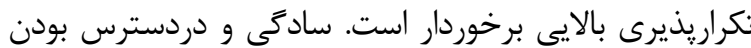

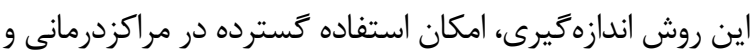

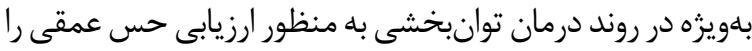

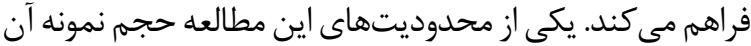
است كه امكان بسط نتايج را محدود مي كند.

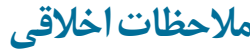

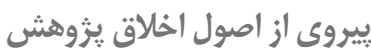

اصول اخلاقى تماماً در اين مقاله رعايت شده است. شركت

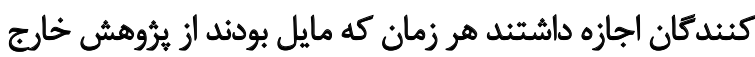

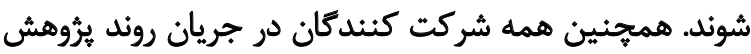

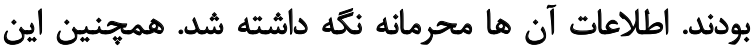

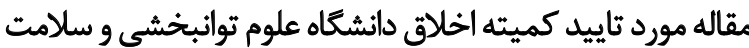
اجتماعى قرار ترفته است.

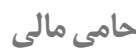

اين تحقيق هيج كونه كمك مالى از سازمان هاى تأمين مالى در بخشهاى عمومى ، تجارى يا غيرانتفاعى دريافت نكردا.

$$
\text { مشار كت نويسندكًان }
$$

تمام نويسندكان در طراحى، اجرا و نتارش همه بخشهاى بروهش حاضر مشاركث داشتهاند.

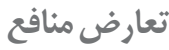

بنابر اظهار نويسندكان اين مقاله تعارض منافع ندارد.

$$
\text { تشكر و قدردانى }
$$

از كليه افراد شركت كنثنده در مطالعه، اساتيد گرامى و همجيجنين

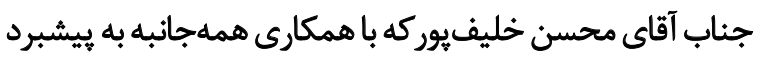
اين مطالعه كمك كردند كمال قدردانى را داريهم. 


\section{References}

[1] Batson G. Update on proprioception: Considerations for dance education. Journal of Dance Medicine \& Science. 2009; 13(2):3541. [PMID]

[2] Sharma L. Proprioceptive impairment in knee osteoarthritis. Rheumatic Disease Clinics. 1999; 25(2):299-314. [DOI:10.1016/S0889857X(05)70069-7] [PMID]

[3] Stillman BC. Making sense of proprioception: The meaning of proprioception, kinaesthesia and related terms. Physiotherapy. 2002; 88(11):667-76. [DOI:10.1016/S0031-9406(05)60109-5]

[4] Cohen HS, editor. Neuroscience for rehabilitation. Philadelphia: Lippincott Williams \& Wilkins; 1999. https://books.google.com/ books?id=mnFOEsSjZ_UC\&dq

[5] Riemann BL, Lephart SM. The sensorimotor system, part II: The role of proprioception in motor control and functional joint stability. Journal of Athletic Training. 2002; 37(1):80-4. [PMID] [PMCID]

[6] Stillman BC. An investigation of the clinical assessment of joint position sense $[\mathrm{PhD}$. dissertation]. Victoria: The University of Melbourne; 2000. https://minerva-access.unimelb.edu.au/handle $/ 11343 / 38786$

[7] Lephart SM, Warner JJP, Borsa PA, Fu FH. Proprioception of the shoulder joint in healthy, unstable, and surgically repaired shoulders. Journal of Shoulder and Elbow Surgery. 1994; 3(6):371-80. [DOI:10.1016/S1058-2746(09)80022-0]

[8] Lephart SM, Henry TJ. The physiological basis for open and closed kinetic chain rehabilitation for the upper extremity. Journal of Sport Rehabilitation. 1996; 5(1):71-87. [DOI:10.1123/jsr.5.1.71]

[9] Kaya D, Yosmaoglu B, Doral MN, editors. Proprioception in orthopaedics, sports medicine and rehabilitation. Cham: Springer; 2018. [DOI:10.1007/978-3-319-66640-2]

[10] Fakoor Rashid H, Fadaei Dehcheshmeh T, Daneshmandi H, Norasteh AA. Investigating knee joint position sense after anterior cruciate ligament reconstruction in male soccer players. Physical Treatments: Specific Physical Therapy Journal. 2020; 10(1):41-8. [DOI:10.32598/ptj.10.1.437.1]

[11] Fyhr Ch, Gustavsson L, Wassinger C, Sole G. The effects of shoulder injury on kinaesthesia: A systematic review and metaanalysis. Manual Therapy. 2015; 20(1):28-37. [DOI:10.1016/j. math.2014.08.006]

[12] Norouzi E, Farsi AR, Vaezmousavi M. Effects of proprioceptive and visual disturbance on inphase and anti-phase hand performance. Physical Treatments: Specific Physical Therapy Journal. 2015; 5(1):41-8. http://ptj.uswr.ac.ir/article-1-164-en.html

[13] Mandehgari Najafabadi M, Azad A, Mehdizadeh H, Taghizadeh $\mathrm{Gh}$. Predictive value of somatosensation for manual dexterity and upper Limb Motor function in stroke survivors. Iranian Rehabilitation Journal. 2018; 16(2):185-94. [DOI:10.32598/irj.16.2.185]

[14] Khodabakhshi M, Ebrahimi-A'tri A, Hashemi-Javaheri SAA, Khan-Zadeh R, Zandi M. [The effect of 5 weeks proprioceptive training on basketball players' dynamic balance inflicted with chronic ankle sprain (Persian)]. Archives of Rehabilitation. 2014; 15(3):44-51. http://rehabilitationj.uswr.ac.ir/article-1-1195-en.html
[15] Pilbeam Ch, Hood-Moore V. Test-retest reliability of wrist joint position sense in healthy adults in a clinical setting. Hand Therapy. 2018; 23(3):100-9. [DOI:10.1177/1758998318770227]

[16] Moharrami R, Shoja'eddin S, Sadeghi H. [The effect of theraband training on position sense of internal and external rotator muscles in male athletes with shoulder impingement syndrome (Persian)]. Archives of Rehabilitation. 2015; 16(3):228-33. http://rehabilitationj. uswr.ac.ir/article-1-1440-en.html

[17] Shaghayegh-Fard B, Ahmadi A, Ma'roufi N, Sarraf-Zadeh J. [The evaluation of cervical position sense in forward head posture subjects and its comparison with normal subjects (Persian)]. Archives of Rehabilitation. 2015; 16(1):48-57. http://rehabilitationj.uswr.ac.ir/ article-1-1539-en.html

[18] Rastgar M, Nodehi Moghadam A, Bakhshi E, Sarabadani Tafreshi E, Toluee S. [Comparison of shoulder proprioception in women with and without generalized joint laxity (Persian)]. Archives of Rehabilitation. 2016; 17(2):128-35. [DOI:10.21859/jrehab-1702128]

[19] Beyranvand R, Sahebozamani M, Daneshjoo A. [The role of ankle and knee joints proprioceptive acuity in improving the elderly balance after 8-week aquatic exercise (Persian)]. Salmand: Iranian Journal of Ageing. 2018; 13(3):372-83. [DOI:10.32598/sija.13.3.372]

[20] Smith TO, Davies L, Hing CB. A systematic review to determine the reliability of knee joint position sense assessment measures. The Knee. 2013; 20(3):162-9. [DOI:10.1016/j.knee.2012.06.010]

[21] Relph N, Herrington L. Interexaminer, intraexaminer, and testretest reliability of clinical knee joint-position-sense measurements using an image-capture technique. Journal of Sport Rehabilitation. 2015; 24(2). [DOI:10.1123/jsr.2013-0134]

[22] Stillman BC, McMeeken JM. The role of weightbearing in the clinical assessment of knee joint position sense. Australian Journal of Physiotherapy. 2001; 47(4):247-53. [DOI:10.1016/S0004 9514(14)60272-5]

[23] Noor R, Olyaei GR, Hadian MR, Talebian S, Bashir MS. A reliable and accurate system of joint position sense measurement. Biomedical Research. 2018; 29(12):2528-31. [DOI:10.4066/biomedicalresearch.29-18-410]

[24] Ager AL, Roy JS, Roos M, Belley AF, Cools A, Hébert LJ. Shoulder proprioception: How is it measured and is it reliable? A systematic review. Journal of Hand Therapy. 2017; 30(2):221-31. [DOI:10.1016/j. jht.2017.05.003]

[25] Goble DJ. Proprioceptive acuity assessment via joint position matching: From basic science to general practice. Physical Therapy. 2010; 90(8):1176-84. [DOI:10.2522/pti.20090399]

[26] Shrout PE, Fleiss JL. Intraclass correlations: Uses in assessing rater reliability. Psychological Bulletin. 1979; 86(2):420-8. [DOI:10.1037/0033-2909.86.2.420]

[27] Irving F, Russell J, Smith T. Reliability of knee joint position sense measurement: A comparison between goniometry and image capture methods. European Journal of Physiotherapy. 2016; 18(2):95-102. [D OI:10.3109/21679169.2015.1127418

[28] Selfe J, Callaghan M, McHenry A, Richards J, Oldham J. An investigation into the effect of number of trials during proprioceptive testing in patients with patellofemoral pain syndrome. Journal of Orthopaedic Research. 2006; 24(6):1218-24. [DOI:10.1002/jor.20127] 
[29] Dover G, Powers ME. Reliability of joint position sense and force-reproduction measures during internal and external rotation of the shoulder. Journal of Athletic Training. 2003; 38(4):304-10. [PMID] [PMCID]

[30] Han J, Waddington G, Adams R, Anson J, Liu Y. Assessing proprioception: A critical review of methods. Journal of Sport and Health Science. 2016; 5(1):80-90. [DOI:10.1016/j. jshs.2014.10.004]

[31] Juul-Kristensen B, Lund H, Hansen K, Christensen H, Danneskiold-Samsøe B, Bliddal $\mathrm{H}$. Test-retest reliability of joint position and kinesthetic sense in the elbow of healthy subjects. Physiotherapy Theory and Practice. 2008; 24(1):65-72. [DOI:10.1080/09593980701378173] 
This Page Intentionally Left Blank 